Po uroczystych laudacjach oraz wystąpieniach uczniów i współpracowników Jubilat podzielił się swoimi osobistymi wspomnieniami i refleksjami. Zaznaczył, że w swojej pracy zawodowej szczególnie cenił sobie zawsze działalność organizacyjną. Przybliżając swoje działania na rzecz powstania Wydziału Pedagogicznego Uniwersytetu Marii Curie Skłodowskiej w Lublinie oraz utworzenia Akademii Pedagogiki Specjalnej, wspominał zarówno o napotkanych na swej drodze trudnościach, jak i sposobach ich przezwyciężenia. Podzielił się także z zebranymi gośćmi swoimi refleksjami dotyczącymi kształcenia młodych pracowników nauki w zakresie historii wychowania.

Oficjalną część spotkania zakończyły gratulacje i życzenia przedstawicieli wymienionych wcześniej środowisk historyków wychowania. Profesor Adam Massalski przekazując Profesorowi Poznańskiemu list laudacyjny od środowiska kieleckiego, wspomniał o odnajdowaniu w aktach zgromadzonych w archiwach rosyjskich licznych Jego wpisów. Natomiast Profesor Juliana Dybiec podkreśliła, że Jubileusz ten to przede wszystkim ,jubileusz dyplomacji i szkoły życia”. Wszyscy uczestnicy wyrazili nadzieję na kolejne równie inspirujące Jubileusze Profesora Karola Poznańskiego. Spotkanie jubileuszowe zakończył występ Chóru Akademii Pedagogiki Specjalnej im. M. Grzegorzewskiej.

\author{
Agnieszka Wałęga \\ UMK Toruń
}

\title{
Międzynarodowa naukowo-praktyczna konferencja „Huculszczyzna w otchłani wieków”
}

Dnia 6 i 7 maja 2011 r. we Lwowie miały miejsce obchody dwudziestolecia tamtejszego Społeczno-Kulturalnego Towarzystwa „Huculszczyzna” (Суспільно-культурне товариство „Гуцульщина” у Львові), należącego do ogólnokrajowego towarzystwa z siedzibą główną w Werchowynie. Rocznicę powstania organizacji członkowie skupieni w lwowskim stowarzyszeniu postanowili uczcić nie tylko zabawą i rozrywką, lecz także przyczynkiem do naukowego poznania tego wyjątkowego regionu.

Huculszczyzna to obszar Karpat Wschodnich znajdujący się obecnie w większości na terytorium Ukrainy, a także po części w granicach Rumunii. Zamieszkujący go górale to jedna $z$ najbarwniejszych grup etnicznych zarówno w Karpatach, jak i w Europie. Po dzień dzisiejszy Huculi zachowali swoje obyczaje, rytuały, wierzenia, mieniące się barwami stroje, muzykę, energiczne tańce, śpiewy, legendy, tradycyjne rzemiosło.

Od wieków ten wyjątkowy obszar i jego mieszkańcy przyciągają uwagę podróżników, pisarzy, malarzy, ludzi nauki. Poznawanie Huculszczyzny i jej mieszkańców stawało się 


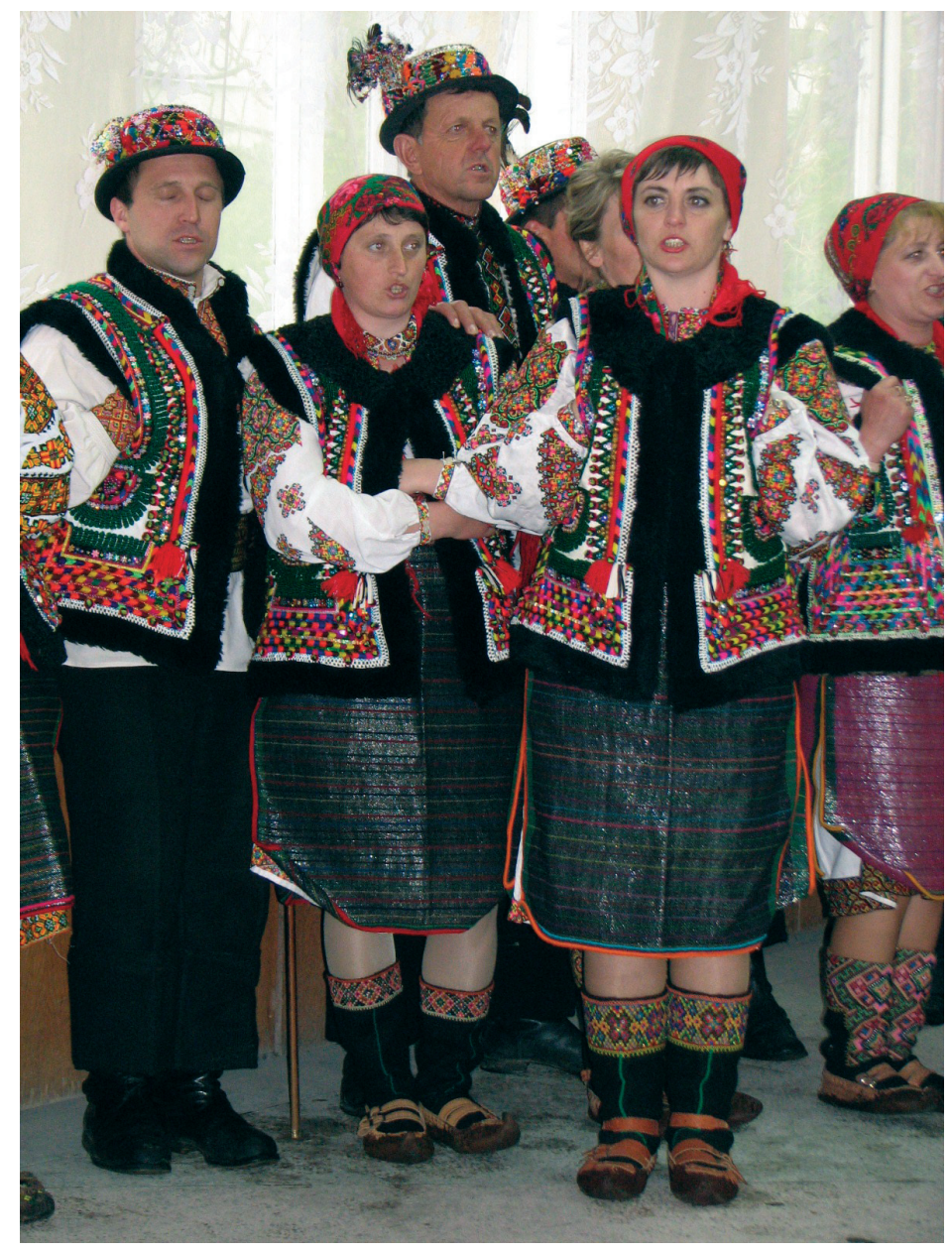

i nadal staje inspiracją dla artystów i badaczy. W początkowym okresie odkrywcami regionu byli ,,przybysze z zewnątrz”. Stopniowy napływ turystów, artystów i naukowców sprawił, że dzikie niegdyś góry zaczęły otwierać się na świat zewnętrzny, a ich mieszkańcy coraz częściej opuszczali rodzinne strony w poszukiwaniu zarobku, łatwiejszego życia oraz wiedzy. W obecnej dobie większość młodych Hucułów zdobywa edukację w dużych ośrodkach akademickich, jak Iwano-Frankiwsk czy Lwów. Spora ich część pozostaje w tych miastach po ukończeniu nauki. Ogromne przywiązanie do „rodzimego kraju” sprawia, że dzięki nim kultura huculska popularyzuje się poza granicami regionu, a Huculszczyzna wciąż jest terenem intrygującym dla ludzi prowadzących działalność naukową we wszystkich dziedzinach.

Huculi we Lwowie pojawiali się od dawna, ale dopiero 29 stycznia 1991 r. zebrała się grupa, która wystąpiła z inicjatywą założenia towarzystwa skupiającego górali, których warunki życia zmusiły do opuszczenia swojej małej ojczyzny. Wszystkich połączyła chęć 

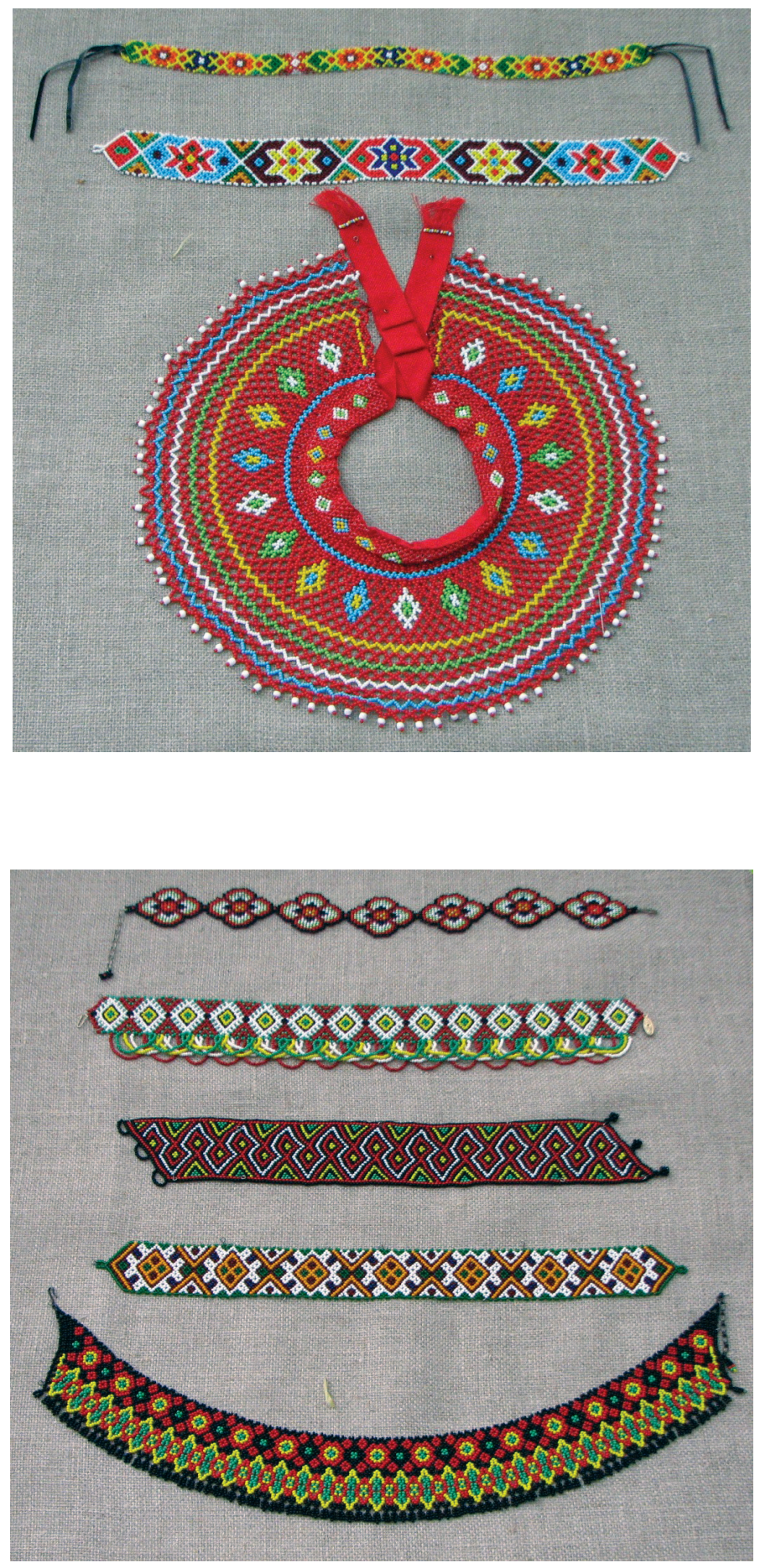

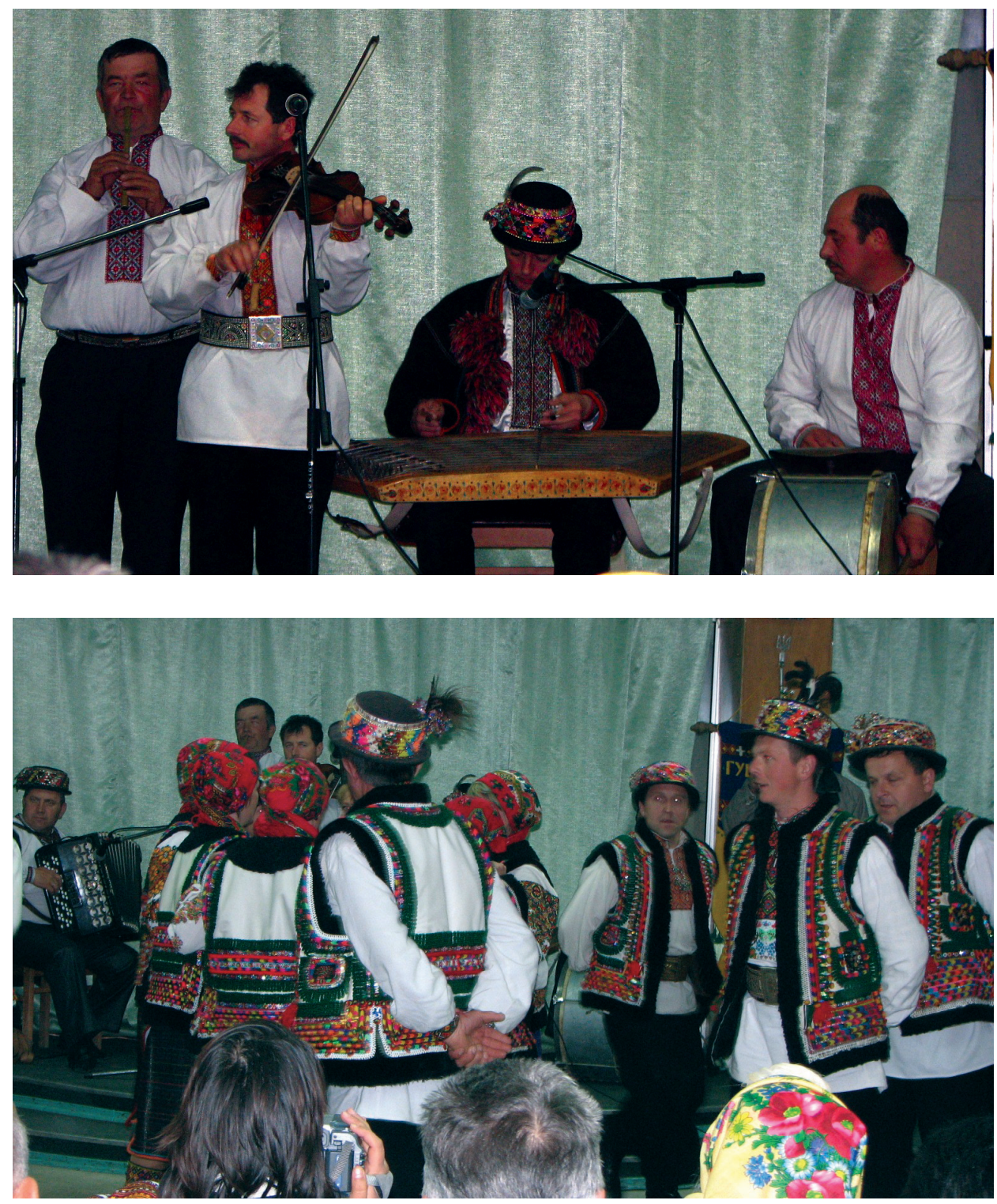

propagowania kultury huculskiej i przybliżenia jej nie tylko sobie, ale przede wszystkim pokazania jej piękna i oryginalności mieszkańcom Lwowa. Opracowano statut, przygotowano pieczęć, proporzec i po dokonaniu rejestracji, tego samego roku, towarzystwo rozpoczęło oficjalną działalność. Do zadań towarzystwa należy m.in.: popularyzowanie huculskiej kultury, rozwój sztuki i tradycyjnego stylu życia wśród mieszkańców miasta i okręgu, współpraca z analogicznymi towarzystwami huculskimi, jak również innymi organizacjami społecznymi, narodowymi i etnicznymi przez wzajemne wizyty delegacji 

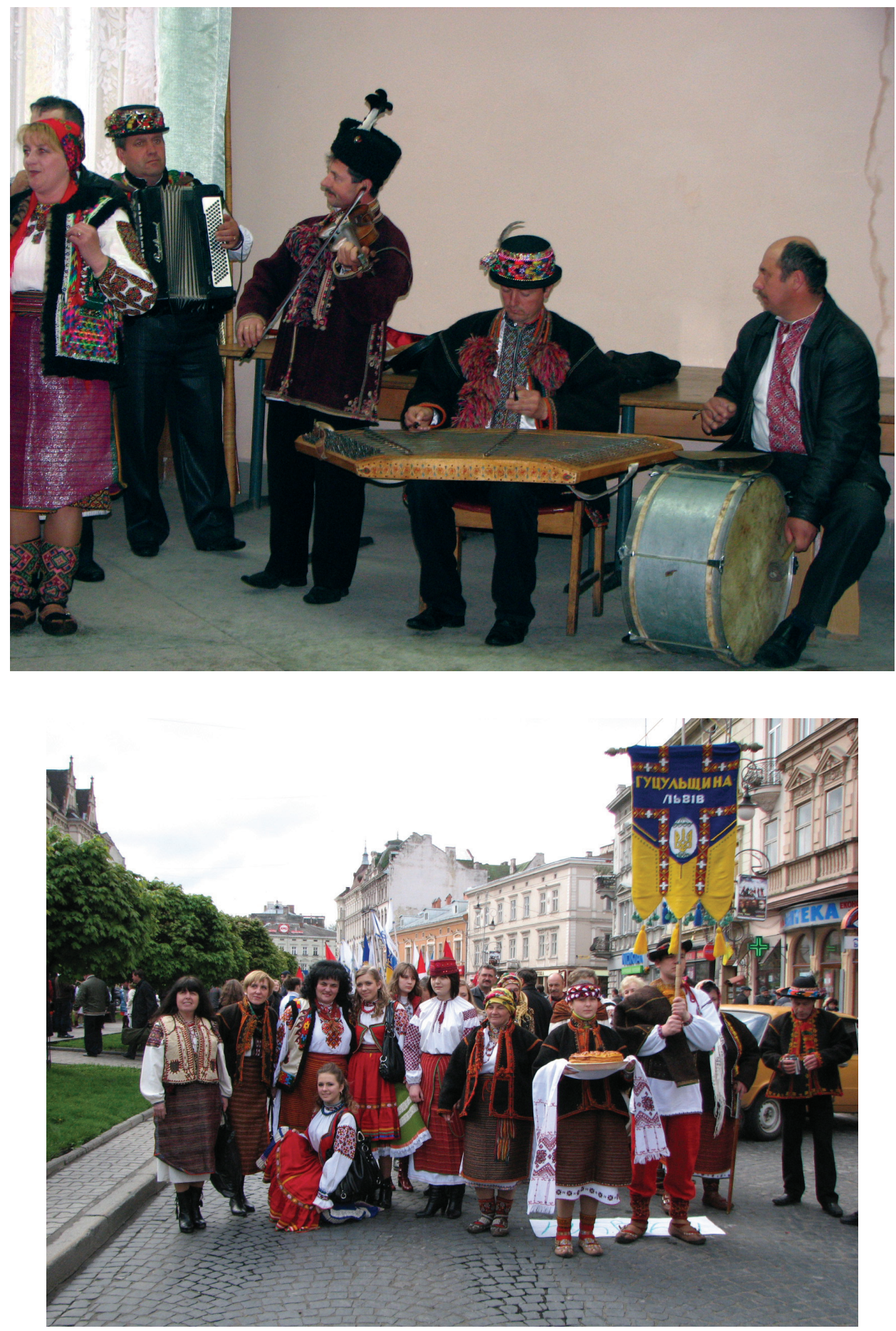


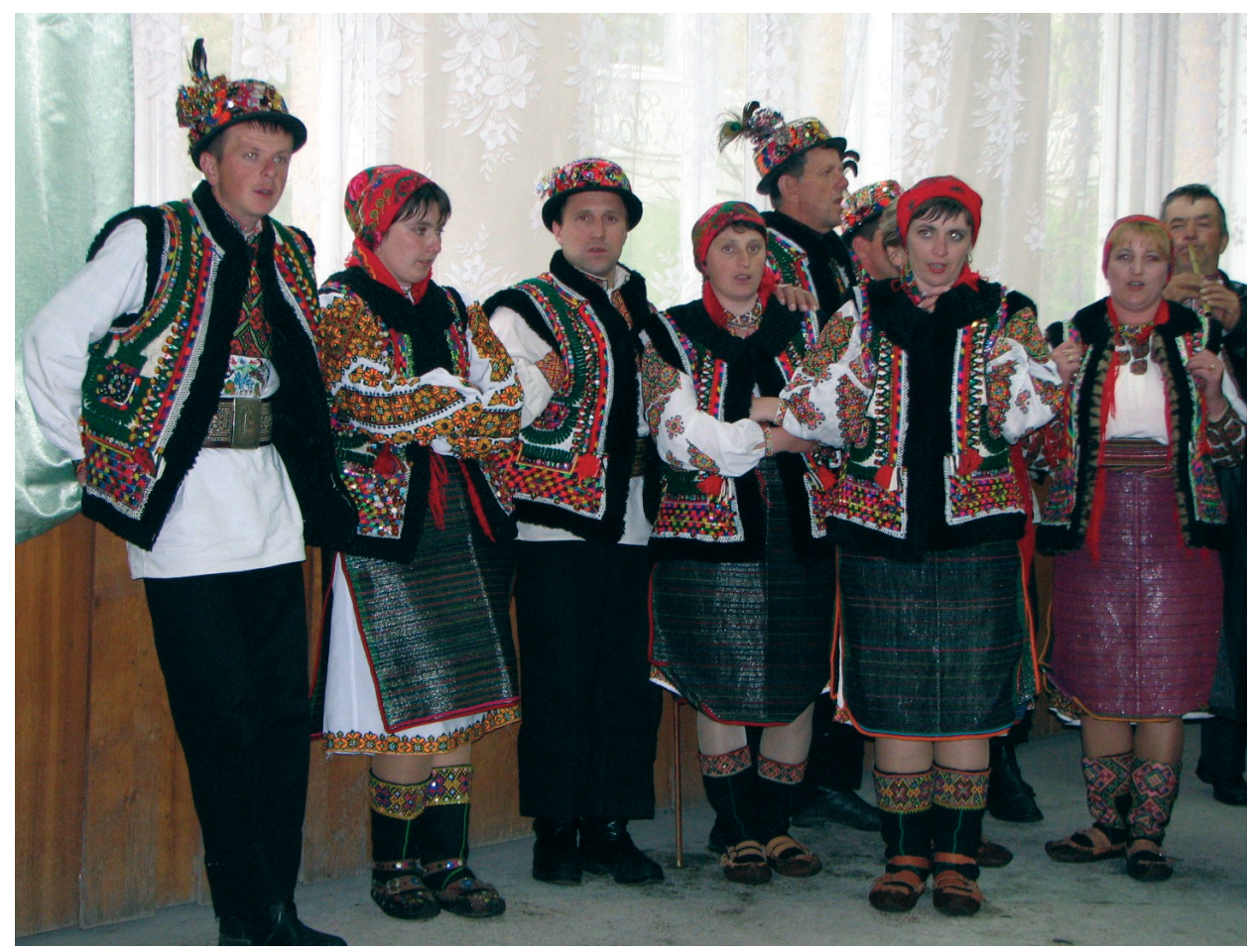

i artystów ludowych, wydawanie naukowych i popularnonaukowych publikacji, organizacja seminariów, konferencji, koncertów itp. ${ }^{2}$

Jubileusz dwudziestolecia działalności uczczono pierwszego dnia międzynarodową konferencją naukową poświęconą temu wyjątkowemu regionowi Karpat Wschodnich i jego mieszkańcom. Obrady przeprowadzono w budynku Państwowego Uniwersytetu Leśniczego (Національни лісотехнічни університет). Wystąpienia zgłosiło 26 referentów, wśród których znalazło się czworo badaczy z Polski: dr Agnieszka Hawrot z Uniwersytetu Jagiellońskiego (Pochodzenie ludów połoniny w świetle tetralogii Stanisława Vincenza „Na wysokiej połoninie”. Huculi, ormianie, żydzi), mgr Justyna Cząstka-Kłapyta z krakowskiej Akademii Sztuk Pięknych ( $O$ źródłach i mechanizmach przemian repertuaru muzycznego w obrzędzie kolędowania męskich grup kolędniczych na Huculszczyźnie - przyczynek do rozważań) oraz dr Małgorzata Ewa Kowalczyk (Staropolskie relacje geograficzne o Huculszczyźnie w XVIII wieku) i dr Anna Haratyk (Życie pasterskie na huculskich połoninach $i$ tatrzańskich halach $w$ XIX i poczatkach XX wieku) z Uniwersytetu Wrocławskiego. Środowisko naukowe Ukrainy reprezentowało znacznie więcej badaczy zarówno uznanych, jak prof. Nestor Bybliuk, prof. Mychajło Hnatiuk, prof. Petro Siredżuk, a także rozpoczynających badania nad różnorodną tematyką dotyczącą regionu.

\footnotetext{
220 років служіння Гуцульщчині, „Гражда” № 1/28/2011, с. 4.
} 


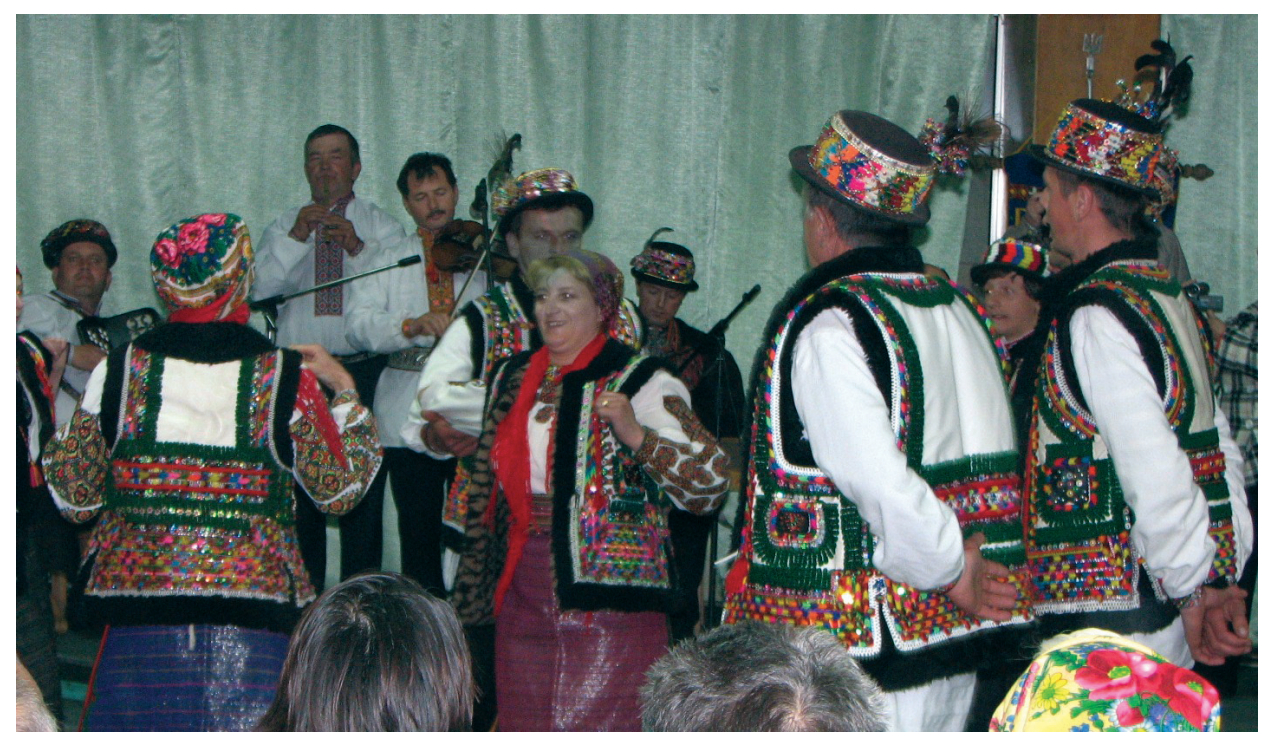

W przypadku naukowców pochodzących z Ukrainy warto podkreślić, że spora część wywodzi się z Huculszczyzny i stanowi kadrę naukową lwowskich i iwano-frankowskich uczelni wyższych. Zarówno ukraińscy, jak i polscy referenci byli przedstawicielami różnorodnych dyscyplin naukowych, co wpłynęło na wielkie urozmaicenie omawianych zagadnień.

Problematyka badawcza prezentowana $\mathrm{w}$ głoszonych referatach była tym samym bardzo zróżnicowana. Można było wyróżnić kilka dziedzin dominujących nad pozostałymi, np. historia, literaturoznawstwo, kultura i sztuka. Spora grupa prelegentów ukazywała problematykę huculską w aspekcie historycznym. Wśród poruszanych zagadnień znalazły się: hodowla zwierząt i pasterstwo jako elementy szczególnie kształtujące kulturę i życie codzienne górali, warunki życia społeczności górskich wsi, historyczno-geograficzne relacje pierwszych odkrywców Huculszczyzny, początki protestantyzmu, dzieje rozwoju turystyki, kolejnictwa wąskotorowego, a także poczty na Huculszczyźnie. Analizie poddano wiele dzieł literackich stanowiących cenny materiał do poznania regionu i jego mieszkańców, a także wskazywano na Huculszczyznę jako częste źródło inspiracji dla pisarzy i artystów, m.in.: Iwana Franki, Romana Fedoriwa, Augusta Bielowskiego, Antina Kruszelnyckiego, Marii Matjus, a zwłaszcza Stanisława Vincenza, którego tetralogia Na wysokiej połoninie wciąż przynosi nowe informacje badaczom. Sporo miejsca poświęcono również kulturze i sztuce huculskiej, podkreślając jej specyfikę, odmienność i unikatowość w skali światowej, a także wpływ na kształtowanie wartości duchowych młodych pokoleń górali.

Teksty referatów, przygotowane wcześniej do druku przez autorów, zostały opublikowane $\mathrm{w}$ recenzowanej pracy zbiorowej Гуцульщчина в гомоні віків pod redakcją Petra 
Siredżuka. Publikacja stanowi cenne ukoronowanie dwudziestoletniej działalności lwowskiego oddziału huculskiego towarzystwa.

Warto dodać, że konferencja była szczególnie cennym spotkaniem dla naukowców z Polski, umożliwiła bowiem nawiązanie nowych kontaktów z ukraińskim środowiskiem naukowym prowadzącym badania w zakresie problematyki huculskiej.

Po prezentacji referatów podsumowano obrady i dokonano ustaleń odnośnie co do dalszych działań oraz współpracy ukraińskich i polskich naukowców. Poruszono między innymi kwestię organizacji kolejnych konferencji nie tylko na Ukrainie, ale i w Polsce oraz przygotowywania publikacji naukowych, co wydaje się być szczególnie cenne dla badaczy z Polski, rozproszonych po wielu ośrodkach naukowych. Omawiano także wspólne przedsięwzięcia mające na celu popularyzowanie Huculszczyzny w obu krajach. Podkreślono w tym miejscu rolę organizowanego cyklicznie w Krakowie przez Centralny Ośrodek Turystyki Górskiej PTTK, Międzynarodowego Festiwalu Huculskiego „Słowiańska Atlantyda”. Ustalono, że planowany na 2013 r. kolejny festiwal będzie odbywał się w kilku polskich i ukraińskich miastach, stwarzając możliwość do spotkań naukowych, prezentacji publikacji o tematyce huculskiej, organizacji warsztatów artystycznych oraz poznania autentycznej kultury prezentowanej przez Hucułów.

Drugi dzień rocznicowych obchodów organizatorzy przeznaczyli na część praktyczną, czyli umożliwili wszystkim chętnym realne zetknięcie się z kulturą huculską. Świętowanie połączono początkowo z obchodami 755-lecia Lwowa, biorąc udział w barwnym korowodzie, który przeszedł głównymi ulicami miasta. Lwowscy Huculi, wsparci licznymi delegacjami z oddziałów Towarzystwa „Huculszczyzna” działającymi na terenie Ukrainy, a zwłaszcza w huculskich miastach i wsiach, prezentowali się wyjątkowo barwnie. Następnie organizatorzy zaprosili wszystkich do lwowskiego skansenu zwanego „Gajem Szewczenki”, gdzie w otoczeniu starych huculskich zabudowań, zespoły miały prezentować muzykę, tańce, śpiewy, tradycyjne stroje, a rękodzielnicy swoje wyroby z drewna, koralików, ceramiki, a także hafty, pisanki itp. Niestety pogoda przeszkodziła w podziwianiu kunsztu artystów ludowych w otoczeniu przyrody i zabytkowej architektury. Zmuszeni do przeniesienia się do budynku Uniwersytetu Leśniczego Huculi, mimo braku miejsca, doskonale zaprezentowali od strony praktycznej to, o czym mówiono w części naukowej konferencji i co mają najpiękniejszego, czyli kształtowaną od wieków materialną i duchową kulturę. Spotkanie to było również okazją do wyróżnienia i nagrodzenia osób najbardziej zaangażowanych w upowszechnianie popularnej i naukowej wiedzy o regionie, kultywowanie tradycji oraz pracę na rzecz towarzystwa. Huculi docenili także działania strony polskiej, w gronie bowiem wyróżnionych znalazł się Jerzy Kapłon, dyrektor Centralnego Ośrodka Turystyki Górskiej PTTK.

Anna Haratyk

Instytut Pedagogiki UWr

Zakład Historii Edukacji 